\title{
Suppressing the Fear, Taming the Warre: Early Modern "Post-Machiavellian" Politics
}

\author{
IVANOVA Y., SOKOLOV P. (2014) KROME MAKIAVELLI: PROBLEMA METODA V POLITICHESKIH NAUKAH \\ RANNEGO NOVOGO VREMENI [BESIDES MACHIAVELLI: THE PROBLEM OF METHOD IN THE POLITICAL SCIENCES \\ OF EARLY MODERN PERIOD], MOSCOW: KVADRIGA. 320 P. ISBN 978-5-91791-171-7
}

\author{
Alexander Markov \\ Doctor of Philology, Senior Researcher, Department of Christian Culture, \\ Institute of World Culture, Lomonosov Moscow State University \\ Deputy Dean, Faculty of the History of Arts, Russian State University for the Humanities \\ Address: Leninskie Gory GSP-1, 119991 Moscow, Russian Federation \\ E-mail: markovius@gmail.com
}

In a sense, this book deals with the ways of taming the underlying civil Warre between early modern authors: from the Giambattista Vico's "most certain criticism of the voluntary action" to Pieter and Johan De la Court's "therapeutic politics." The terrifying perspective of the "catastrophe and disaster", which pushed Machiavelli to the extremes of political ammoralism, permeated the reflection of both his admirers and critics, causing them to seek refuge in the Sovereign's will, in the double-edged rhetoric of the "beneficent violence," or in the shady hypothesis of the physiological substrate of sociability (W. Harvey, R. Cumberland).

Do not be mislead by the title: this book is not about how political theory as a strict discipline found its own method in resisting Machiavellian voluntarism. The authors are well aware that polemics contra Machiavelli are not enough to transform ethical or practical observations into political science. Ivanova and Sokolov have chosen much broader research perspective: if we want to answer the question, "How does method work in political science?", we need to explore generally how methods have emerged in the humanities. The main question is: what happened in the humanities when they ceased to be a kind of art, but were yet to become a form of institutional knowledge?

This period in European culture does not have a clear interpretation, and it is tempting to reduce it to the problem of independent humanities against the institutional logic of universities and scientific communities. But it would be a bad idea to invert the historical perspective. Even if we could talk about the dispute between Renaissance humanists and institutional logic, it is unlikely that further discussion could be represented as the revenge of the institutions. It is also tempting to see in the development of political science from Machiavelli to Hobbes, the construction of extremely broad world-thinking projects, reducing the political problem to the problem of switching from theory to prac-

() Alexander Markov, 2015

(c) Russian Sociological Review, 2015

DOI: $10.17323 / 1728-192 \mathrm{X}-2015-4-204-208$ 
tice. Some authors, inspired by the concepts of Hannah Arendt, are likely to do so, but I doubt whether such approach will lead us from the history of philosophy into the realm of the humanities.

Ivanova and Sokolov seriously argue against Walter Benjamin, Carl Schmitt and Giorgio Agamben, accusing them of establishing the opposition of ordinary and extraordinary politics, and considering these various concepts of power as attempts to return to the pragmatic sense of ethical actions for a sovereign ruler. The need to analyze sovereignty as an ethical phenomenon led these great minds to see the idea of sovereignty as a fiction of independence, with sophistic more than philosophical roots. For Ivanova and Sokolov, the European concept of sovereignty emerged not from the frustration of the irrational, but from a conscious rationalization of the irrational nature of public interest. State interest is not the courage to act in favor of public or private benefit, but an attempt to overcome the opposition of Public and Private through the introduction of the concept of state itself, in order to transform the rhetorical topos of stability and permanence into the topos of the state (of affairs).

The peculiar "pan-rhetoricism" of the Ivanova and Sokolov book, their willingness to display political concepts and even political practices from the literal understanding of the rhetorical figures, has an undeniable rationality, even though we cannot accept their arguments as the only possible interpretation of cultural development.

Ivanova and Sokolov's argument moves from the fact that Renaissance historical, rhetorical and political practices were in the same discourse of non-compulsory decisions, and therefore the structuring of history in the text and the production of political structures were under the same logic. This book marks an effort in new Renaissance studies to focus on the history of practices, rather than the history of individual political figures or ideas.

Despite the absence of an index overcomplicating the use of this insightful book, it is clear that the ideas of such thinkers as Michel Foucault and Quentin Skinner underwent critical processing in the book. The authors discuss at length how ethical guidelines become a device of political theory and of the humanities. Although the link between the armature public occupations of early humanists and the normalization of the political doctrines of modernity is proved in the book with a number of interesting, unexpected and compelling examples, such examples are too scattered throughout the book, and this lack of index and cross-references is frustrating.

The research part of the book takes only 160 pages of the 310-page text. Almost half of the book is comprised of excerpts from the works of the authors discussed, in Russian translation. The reader is invited to look into this anthology, to listen to the original voice of the tradition: Ivanova and Sokolov, as translators, tried to convey the Baroque style, and to reproduce all literary figures and sometimes odd surprises of the style. The book contains the following sources: Book I of the treatise on The Reason of State by Giovanni Botero, an excerpt from the book On the Reason of State by Lodovico Zuccolo, chapters from the book On the Mysteries of State by Arnold Clapmarius, a chapter from the book Coup d'état by Gabriel Naudet, and two chapters from the book On the Consistency of 
Philology by Giambattista Vico. Further there are excerpts from sources which do not treat political problems in the strict sense, but civic life from the point of view of the general laws of the universe. These sources reflect the pursuit to naturalize politics in early modernity. There are chapters from the works: German Konring's Propolitica, Paolo Mattia Doria's Civil Life, Johan and Pieter de la Court's Political Discourses and Considerations of State, or Political Balance, Richard Cumberland's Treatise on the Laws of Nature, Giambattista Vico's On the Study Method of Our Time, and Johann David Müller's A Schematic Sketch of the Method of Civil Prudence. Translations are provided with bibliographical notes and a glossary of key terms, although, unfortunately, a bibliography of these sources and the available translations in Russian or other languages is absent. The commentaries have their legacy in the Soviet tradition, where commentaries on translated texts were the least censored and therefore combined into an encyclopedic reference. Soviet authors achieved real skill in the retelling of a whole scholarly argument in several lines of fine print. The authors of this book have probably not managed to create the impression of the all the world's culture in a few pages but they form an illustration of the friendly circle where Dilthey can be on a par with the Russian professor Makhlin.

The first part of the book, called "Anti-Machiavelli," is devoted to the theological and political controversies in the era of the Counter-Reformation. It is a detailed look at how a complicated exegesis of the Bible helped to explain the notion of community in the secular space, and the work of Caesar Baronius already in this seed have an idea of the church community as a constant source from which volatile civilian communities were deployed. The desire of Church historians to discredit civil life has become its legalization. It can be questioned, whether this legalization was achieved by textual means, or through the establishment of new institutions by papal Rome; this, however, is beyond the scope of the book.

Considering the legacy of Giovanni Botero, a famous critic of Machiavelli, Ivanova and Sokolov demonstrate his work as an eccentric variation of the political ideas of the aesthetics of classicism, such as credibility and hypocrisy. The origins of Diderot's "paradox of the actor" can be seen in the discussion of Botero's criticism of the pretenses of Numa Pompilius. In this case the literary-critical interests of the authors of the book take precedence over ethics and politics, but careful study of the history of exegesis allows them to prove how ways of reading the Bible were transformed for reading profane history.

The authors subtly note that this transformation was not a conscious program, but the result of the inertia of language and familiar formulas, derived from preaching and religious education. Botero "creates a special political-theological logic, which allows him to combine Christianity understood as the immanentist control technology, and Christianity as a form of transcendental justification and propagation of political domination of the Catholic Church throughout the ecumene" (p. 43). If the reader is ready to wade through such a cumbersome phrase, his diligence will be rewarded, just as the zeal of the lover of historical pieces is rewarded with scenic paradoxical characters. 
Explicating the intellectual history of the concept of Reason of State, Ivanova and Sokolov see not only a political concept but also a fictive general goal of civilization. Here we could talk about the profanation of divinity, and even about the profanation of Aristotelian metaphysics and ethics. This concept eventually anticipated the neutral concepts of science, such as space.

The end of the first part of the book is an unusual presentation of Giambattista Vico's conception of the origin of social and political life from the experience of shame, not (as ancient authors claimed) from a sense of self-protection, love or friendship. Vico's case is studied as an example of the exhaustion of the old rhetorical arguments invented in favor of political community and the need to invent another reason for its establishment.

The origins of such a concept of shame are rooted in the Renaissance understanding of shame as a means to overthrow tyranny and to restore a republic. It is enough to point to a picture by Lorenzo Lotto (c. 1533), depicting the image of a woman dressed as Lucretia with the figure of Lucretia. Shame was conceived very early as radical political action. Ivanova and Sokolov speak in detail about the tragic form of politics that inspired Vico, presenting radicalism as a kind of tragic aesthetic.

Generally, the book will be not easy for a specialist in political theory to read because of the large number of unexplained terms from literary criticism. It corresponds to the Russian tradition, where literary criticism became, after the discredit of the philosophy of Marxism-Leninism, the basic norm of humanities. The second part of the book is entitled "Mathesis Politica" (political science), which reconstructs the appearance of the object and method of the science. This part is the most innovative, since for Ivanova and Sokolov the development of the concept of method and the development of natural philosophy are both tools for the inauguration of science. Politics is an area where you have to act like nature-a formula which immediately recalls Aristotle's mimesis. Hence the emergence of political science marks the collapse of the aesthetics of Aristotle.

For Ivanova and Sokolov the legacy of Hobbes is associated not only with a rational philosophy, but with the rhetoric: "once the a priori principles for political practice have only a limited import (or else Hobbes would have to return to the humanistic normative model), they must be implemented by the principles that can only be found (in the sense of the rhetorical inventio) in, or drawn from social life" (p. 131). Unfortunately, the authors do not give an explanation on how the word "invention" has gained the modern meaning: not a rhetorical search for a suitable material for the speech, as in classics, but the creation of new gadgets for speech and research. It is shown how the political theory of Hobbes, which becomes a kind of general working model of all modern political thinking, contaminated anthropological intuitions, semiotics, natural philosophical arguments, and rhetoric. This reconstruction of work patterns is reminiscent of Soviet semiotics, its "secondary modeling systems."

The semiotics of abstract ideas, as a magic tool of analysis, forcing into existence not only the thoughts and feelings of the people of the past but past concepts and abstract theories, is more than commendable. Interdisciplinary cooperation, necessary for this new approach to Hobbes, relies on the huge cultural erudition of the authors of the book. 
If it were not for the need at each page to keep in mind what was said ten pages before, one would immediately take up the translation of this book (in any case, the research part). Such translation would be desirable, after additional linking, indexing and the addition of a full bibliography.

\title{
Вытесняя Fear, приручая Warre: «постмакиавеллистская» политика раннего Нового времени
}

\author{
Александр Марков \\ Доктор филологических наук, ведущий научный сотрудник отдела христианской культуры Института \\ мировой культуры Московского государственного университета имени М. В. Ломоносова, заместитель \\ декана факультета истории искусства Российского государственного гуманитарного университета \\ Адрес: ул. Ленинские Горы, д. 1, Москва, Российская Федерация 119991 \\ E-mail:markovius@gmail.com
}

Рецензия: Иванова Ю. В., Соколов П. В. (2014) Кроме Макиавелли: проблема метода в политических науках раннего Нового времени, М.: Квадрига. 